\title{
28 Research Soure \\ Chemical Modification of Nisin With Homocysteine Thiolactone And Its Antibacterial Activity
}

\section{Research Article}

Keywords:

Posted Date: November 17th, 2021

DOI: https://doi.org/10.21203/rs.3.rs-649358/v2

License: (c) (i) This work is licensed under a Creative Commons Attribution 4.0 International License.

Read Full License 


\section{Abstract}

The full text of this preprint has been withdrawn by the authors due to author disagreement with the posting of the preprint. Therefore, the authors do not wish this work to be cited as a reference. Questions should be directed to the corresponding author.

\section{Full Text}

The authors have withdrawn this preprint from Research Square. 